\title{
化合繊各社の3Rへの取り組み状況と 今後の方向
}

\author{
大橋庸二 OHASHI Youji \\ 東レ株式会社
}

\section{1..はじめに}

日本化学繊維協会・合繊リサイクル専門委員会構成各 社は, 自社の生産活動で発生する廃棄物の減量化やリサ イクル，不要となった繊維製品のリサイクル，3Rに配 慮した新技術の開発, 再生原料の利用等, 循環型社会構 築への貢献を目指した活動に積極的に取り組んでいま す.

以下に，化合繊各社の $3 \mathrm{R} へ の$ 取り組み状況と今後の 方向について説明します.

\section{2. 合繊リサイクル專門委員会}

日本化学繊維協会・合繊リサイクル専門委員会は, 緎 維製品 $3 R$ 推進会議 (経産省) への対応, 瀻維製品リサ イクルにかかわる法制度・技術上の諸問題についての検 討, 廃棄物・リサイクル政策の動向把握，リサイクルヘ の取り組みに関するPR（エコ展への業界としての出展） や関連他団体との連携を図るための専門委員会です.

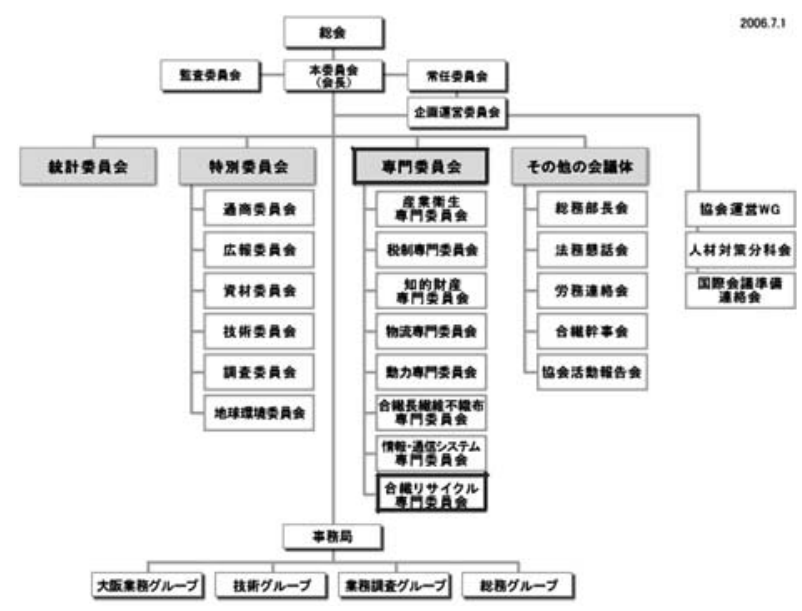

日本化学繊維協会組織図

\section{3. 繊維製品のマテリアルフロー}

日本の緘維業界の流通構造は複雑ですが，主なものを 単純化したマテリアルフローは右図に示す通りです.

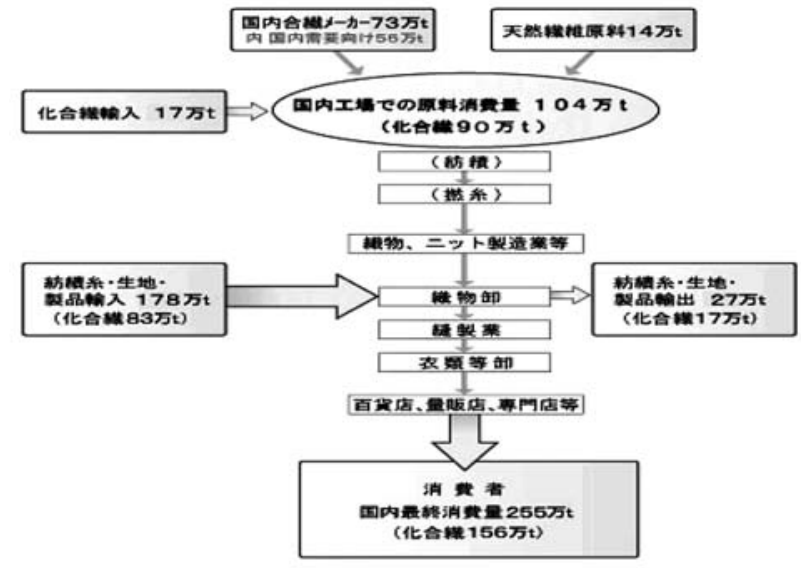

出所：日本化学繊維協会（推定）(経産省繊維統計, 財務省貿易統計ベース) 繊維業界の流通構造の概略とマテリアルフロー

2006年の国内繊維最終消費量は 255 万 $\mathrm{t}$ ですが，この 内 178 万知製品等輸入で占められており, 国内工場で

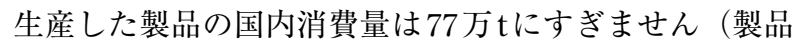
等輸出 27 万t含めて, 国内の生産量は 104 万 $\mathrm{t})$.

化合繊に限ると最終消費量は全体の $61 \%$ に当たる 156

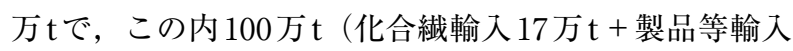
83 万t）が輸入品で占められており，製品などの輸出を 全て国内合繊メーカー品と仮定すると，国内市場で日本 化学纎維協会会員企業が関与する国産品は $36 \%$ に当た る56万tです.

用途別に見ると，衣料用は国内工場の糸消費量の $30 \%$ 弱（化合繊のみの場合も同様）と推定されますが, 製品輸入は衣料品関係が多いため, 国内最終用途の大半 は衣料用で, その他, 家庭用（寝装品, インテリア, 身 の回り品等）や産業用で消費されます.

このように，多様な用途があること，素材投入から最 終製品が消費者の手に渡るまで, 長く複雑なルートを経 由すること, 多くの素材と複合して使用されることが多 いことなどから，川上に位置する我々には，全体を把握 しにくい面があります.

このような状況の中で, 日本化学纎維協会会員各社は, 可能な限り $3 R$ の推進に取り組んでいます. 


\section{4. 化合繊工場で発生する絨淮屑の減 量化とリサイクルヘの取り組み}

化合繊工場では，以前（特にオイルショック以後）か ら工場で発生する繊維屑の減量化およびリサイクルに取 り組んできました。

下表に示すとおり，「リサイクル率」は $93 \%$ (2001年) から 98\%（2006年）に向上し，「産業廃棄物委託処分量」 は4000トンから800トンに減少しています.

「リサイクル率」は，既に高い水準に到達しており， 今後も, 現状水準を維持できるよう取り組みを推進しま す.

ポリエステル，ナイロン，アクリル工場の繊維屑発生量とリサ イクル率

単位：トン

\begin{tabular}{|c|c|c|}
\hline & 2001年 & 2006年 \\
\hline (1) 3素材合計生産量 & $1,170,000$ & 849,000 \\
\hline (2) 繊維屑発生量 & 57,000 & 40,600 \\
\hline (3) 屑発生率：(2)/(1) X100) & $4.9 \%$ & $4.8 \%$ \\
\hline (4) 工場内リサイクル量 (熱回収を含む) & 24,000 & 9,600 \\
\hline (5) 工場外リサイクル量 & 29,000 & 30,200 \\
\hline (6) 産業廃棄物委託処分量 & 4,000 & 800 \\
\hline (7) リサイクル率：(4)十(5)) / (2) ×100 & $93 \%$ & $98 \%$ \\
\hline
\end{tabular}

\section{5. 繊維製品リサイクルヘの取り組み}

合繊リサイクル専門委員会構成各社は，アパレルや小 売等のユーザーと連携したリサイクルシステムを構築 し，ユニフォーム等をはじめとする自社関連製品のリサ イクルに取り組んでいます。

合繊リサイクル専門委員会では 2003 年から構成各社 の「繊維製品リサイクル実績調査」を実施していますが, 同結果によると，2003年の回収・リサイクル実績は 330 トン，2006年は 380 トン（すべてがユニフォームと仮定 すると約 38 万着に相当する（備考：ユニフォーム着数 (参考) は $1 \mathrm{~kg} /$ 着（上下 1 セット）として換算)）とな っています。

\begin{tabular}{|c|c|c|c|}
\hline 会社数 & 対象 & $\begin{array}{l}\text { リサイクル } \\
\text { 手法 }\end{array}$ & $\begin{array}{l}\text { 実績数量 } \\
(2006 \text { 年) }\end{array}$ \\
\hline 7社 & $\begin{array}{l}\text { ユニフォーム,寝装・ } \\
\text { インテリア,産業資材等 }\end{array}$ & $\begin{array}{l}\text { ケミカル,マテリ } \\
\text { アル,サーマル }\end{array}$ & 380トン \\
\hline
\end{tabular}

上記の通り，化合繊各社でのリサイクルは，ケミカル， マテリアル，サーマルなど種々のリサイクル手段を活用 しています。手法別の概要は以下の通りです.

\section{・ケミカルリサイクル}

ユニフォーム等の衣料品の場合，製品の表地や裏地な どをナイロン $100 \%$ や゚゚リエステル 100\%（または $80 \%$ ) とする等，易リサイクルに配慮した商品について，回収 後にケミカルリサイクルするリサイクル企画が数社で実 施されています。
この場合，商品企画面では「リサイクルが容易な商品 設計」として「マーク」を付け, 特定ルートで販売し, 同ルートの逆ルートで回収し, リサイクルするシステム が採用されています。

ポリエステルの場合には，他素材が混入しても処理可 能なリサイクル技術を開発しており, 衣料品は回収され, 合繊工場にて解重合工程を経て，原料のDMT（ジメチ ルテレフタレート）に戻し，自社のポリエステル繊維原 料として利用します。

ナイロン $100 \%$ の場合には，同じく，回収して，合繊 工場で解重合工程を経て，原料のカプロラクタムに戻し て自社のナイロン繊維原料として利用します.

この他，ケミカルリサイクルの新しい手法として，繊 維製品（合成繊維または合成樹脂を含む繊維製品）を回 収し, 化学原料や燃料などの資源として再利用するリサ イクルシステムが開発されています。

今後も, 回収システムの最適化や高効率化・コスト低 減に向けた取り組みを推進します.

・マテリアルリサイクル

ユニフォームなどでポリエステル $100 \%$ の場合は，上 記ケミカルリサイクル以外の方法として，回収してポリ エステル製のボタンやファスナーなど成型品として利用 するマテリアルリサイクルも行われています。

今後も，更なる用途開発に向けて取り組みを推進しま す.

・サーマルリサイクル

複数の企業が，自社工場の発電用ボイラーなどで，繊 維製品廃棄物を燃料として利用し，電力や熱エネルギー に変換して活用するサーマルリサイクルへの取り組みを 行っています。

リサイクルの原点は, 省資源と環境保全にあると捉え, 特に, 多様な素材・加工剂が使用される一般衣料の場合, リサイクルを進める上で，マテリアルやケミカルリサイ クルでは，かえってエネルギー増やコスト増になるよう なケースもあります。サーマルリサイクルにはCO2 の 発生等問題点もありますが，現状ではレスエナジーの観 点から必要なリサイクル手段と考えます。

\section{6. 化合繊各社のリサイクルの取り 組み}

化合繊各社が現在取り組んでいる使用済み繊維製品の リサイクルは，ユニフォーム（工場等向けの制服・作業 服）をはじめとする特定ユーザー向け製品が中心です.

特定ユーザー向け製品では，(1)回収が比較的容易で， (2)回収量も縓まり易い，(3)グリーン購入法もあり，易リ サイクル商品企画や回収費用の分担が比較的容易なこと が理由です。

一方，一般衣料品の場合は，(1)廃棄物処理法上の制約 
が大きいこと，(2流通が零細で，極めて複雑なこと，(3) 輸入製品の浸透率が高いこと, (4)多様な素材・加工等, 一律なリサイクル方法では対応が困難なことなど, 素材 供給の立場にある化合繊各社がリサイクルを推進するこ とは極めて難しい状況にあります。

化合繊各社のリサイクルは企画開始後それほど時間が 経っていないこともありますが, 現状の回収量は全体か ら見ればわずかな数量にとどまっています.

しかしながら, 化合繊各社では, 今後とも, それぞれ の素材に適したより効率的なリサイクル技術の開発， ユ ーザーと協力したリサイクルシステムの改善, 回収商品 の用途開発に全力をあげて取り組み，実施可能な部分か ら繊維製品のリサイクルを拡大して行きたいと考えてい ます。

また，リサイクルの更なる拡大のためには，次のよう な，官民一体となった取り組みも欠かせません．

これら課題については繊維製品 $3 \mathrm{R}$ 推進会議（経済産 業省）での検討成果が上がることが望まれます.

\section{7. 繊維リサイクル推進上の課題}

\section{（1）課題1 (法律)}

現状，市場から繊維製品を回収しょうとした場合，一 般には廃棄物処理法の適用を受けますが, 同法は「廃棄 物処理責任の明確化と適正処理の実行」の視点による法 律であり, リサイクル推進の観点からは同法の規制が障 害となるケースが多くあります.

リサイクル推進のためには, 回収品を単なる廃棄物と してではなく, 資源としての観点からの規制緩和が望ま れます。

\section{(2) 課題2（出口対策）}

グリーン購入, エコマーク等エコ商品の拡大を後押し する制度がありますが, 基準が統一されておらず, また, 必ずしも, リサイクルを促進する方向ではありません.

例えば, グリーン購入法の調達対象製品は, 䋊維製品 の場合，ボトル等から再生したPET繊維を使用したも のが中心で, 使用済み繊維製品の回収・リサイクルを促 進する制度ではありません。

今後, リサイクルをさらに拡大して行くためには, 使 用済み繊維製品の回収・リサイクルを後押しする制度が 必要です。

\section{（3）課題3（啓発活動）}

繊維製品のリサイクルには, 一般市民の協力が欠かせ ません.リサイクルの意義を充分に告知し，啓発して行 く必要があります.

その前提として, 誰もが納得する, 業界共通のエコ評 価基準を作り客観的にリサイクルを評価できる仕組みが 必要です.

さらに, 行政, 消費者サイドとも一緒になって, 循環
型社会形成の啓発と製品購入を促進する制度が必要で す.

\section{（4）課題4（コスト）}

回収・リサイクルに掛かるコスト問題をクリアするた めに, 効率的な回収システム, 合理的なコスト負担の割 り振り等, 現実に即した制度や仕組みが必要です。これ らについて更なる議論が期待されます.

\section{8. $3 R$ に配慮した新技術の開発}

\section{（1）各種リサイクル技術の開発}

3 大合繊の内，ポリエステルとナイロンに関しては, ケミカルリサイクルによって, バージンと同等の品質の ものにリサイクルする技術が開発されています.

この他, 䋊維製品（合成繊維または合成樹脂を含む繊 維製品）を回収し，化学原料や燃料など資源として再利 用するリサイクルシステムも開発され, 環境省から広域 認定制度の認可を取得しています.

\section{（2）生分解性繊維の開発}

従来からある自然分解性の化学繊維（キュプラなどの 再生繊維) に加えて, 新たな展開として, 生分解性繊維 (ポリ乳酸繊維) が開発され, 土木資材 (植生資材, 法 面保護材, 土壤補強材など) や農業資材（農業用シート, 防草袋・マット, 育苗ポットなど）など土中に放置した ままで使用される用途を中心に, 包装資材（袋，ロープ， 紐など), 生活資材 (ボディタオル, 水切りネット, 日 用雑貨品, 包装材など), 衣料用 (ポロシャツ, Tシャ ツ，ユニフォーム，インナー，セーター，靴下など）等 への使用が研究・開発されています.

リデュースに貢献するサスティナブルな素材として, 今後も積極的に推進します.

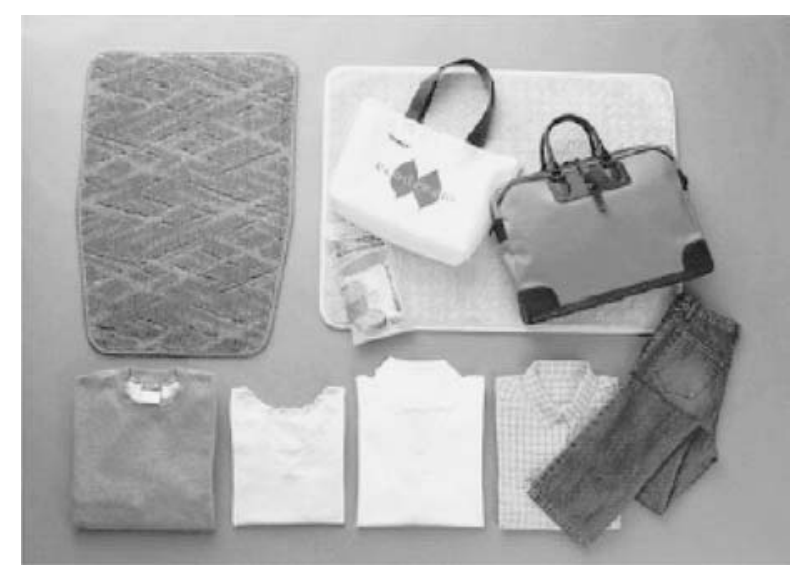

各種のポリ乳酸繊維製品

\section{9. 再生原料の利用による循環型社 会構築への貢献}

再生品の利用として, 再生 PETボトル樹脂を使用し 
た繊維製品の展開がほとんどのポリエステル繊維製造メ ーカーで実施されています。

この場合，各企業とも独自のマークまたはエコマーク を貼付して, エコ商品であることをアピールする等, ア パレル，小売りなどのユーザーと協力した商品展開を実 施しています。

化合繊各社は, 今後も環境対応製品として用途拡大を はかり, 再生PET樹脂の使用量を増加させ, 循環型社 会構築に貢献したいと考えています.

しかし, 一方で再生 PETボトルなどの海外流出問題 は, 原料 (再生PET樹脂) 調達に深刻な影響を及ぼして おり，国内で作り上げてきた再生 PET樹脂を使用する ビジネス構造や仕組みの崩壊につながりかねない問題と なっています。

省エネ・環境負荷低減に貢献する我が国リサイクルシ ステムを維持するために制度の改革を期待します。

\begin{tabular}{|l|c|c|}
\hline & \multicolumn{2}{c}{ 単位 : トン } \\
\hline 再生PET樹脂の使用量 & 2001年 & 2006年 \\
\hline
\end{tabular}
(参考:ポリエステル繊維生産量63万トン (2001年),48万トン (2006年))

\section{0. 各種教育機関 ·消費者団体等へ の情報発信と対話促進}

広く一般消費者（主婦, 学生など）を対象に, 環境・ リサイクル問題についての対話を促進するとともに, 教 育機関や消費者団体などに向けて積極的な情報提供を行 っていきたいと考えています.

その活動のツールとして, 化学䋊維と環境・リサイク ルについての小冊子を2004年3月に発行しました.

また, 東京ビッグサイトにて開催されているエコプロ ダクッ展（環境総合展）に2004年度から 4 年続けて日本 化学繊維協会コーナーを出展し, 化合繊業界の環境・リ サイクルへの取り組みを紹介しています。

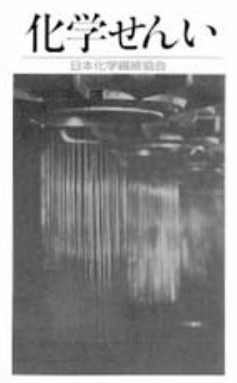

化学繊維と環境・リサイクルについての小冊子

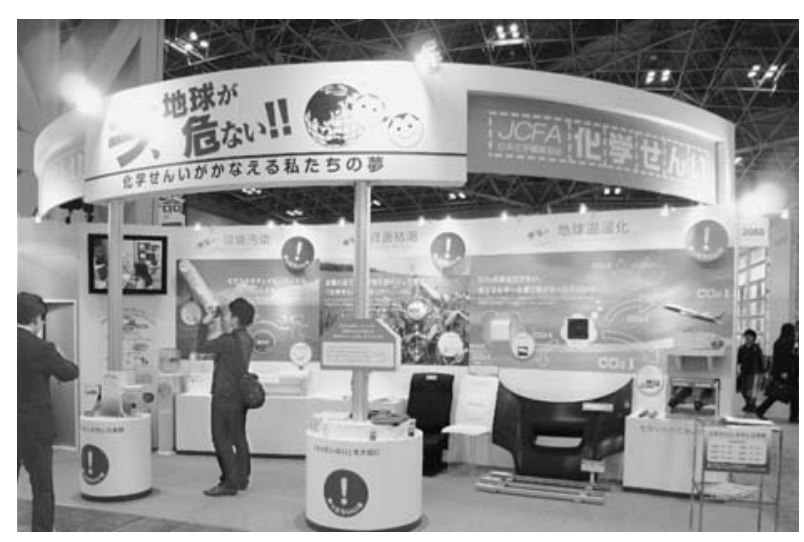

エコプロダクツ 2007 展 日本化学繊維協会ブース
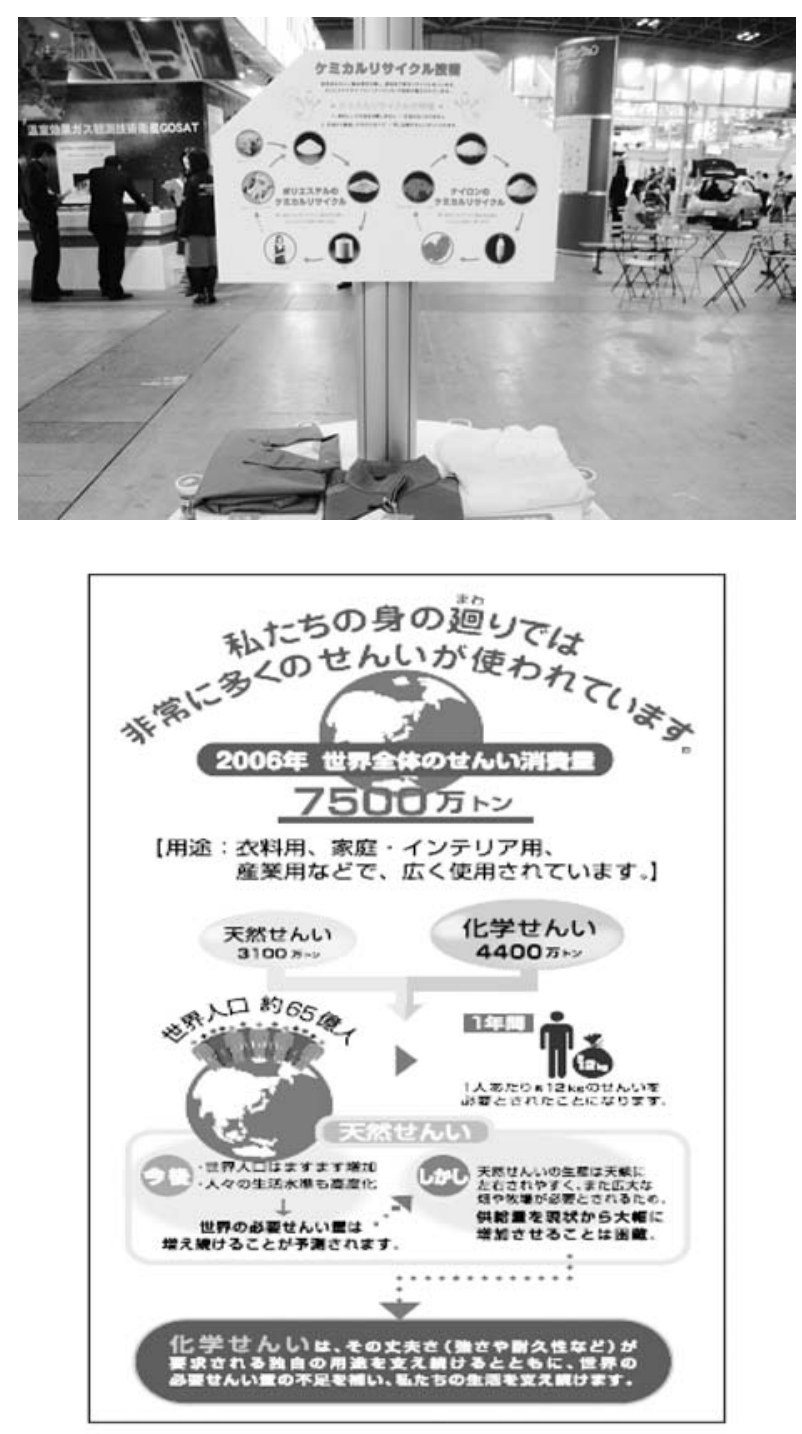

\section{1. $3 R$ アクションプランの継続策 定と公表}

3Rアクションプランは, 日本化学繊維協会ホームペ ージ（http://www.jcfa.gr.jp）上で公表しています (2001年の取り組み実績より公表). 今後とも適宜状況 を把握し, 公表内容の見直し・評価を行う予定です. 


\section{2. 日本化学繊維協会 - 合繊リサイ クル専門委員会構成各社（7 社） の3Rへの取り組み}

（1）帝人

\begin{tabular}{|c|c|c|}
\hline & \multicolumn{2}{|c|}{ 帝人 } \\
\hline 商品名 & ＜帝人ファイバー> & ＜東邦テキスタイル > \\
\hline 企画名 & 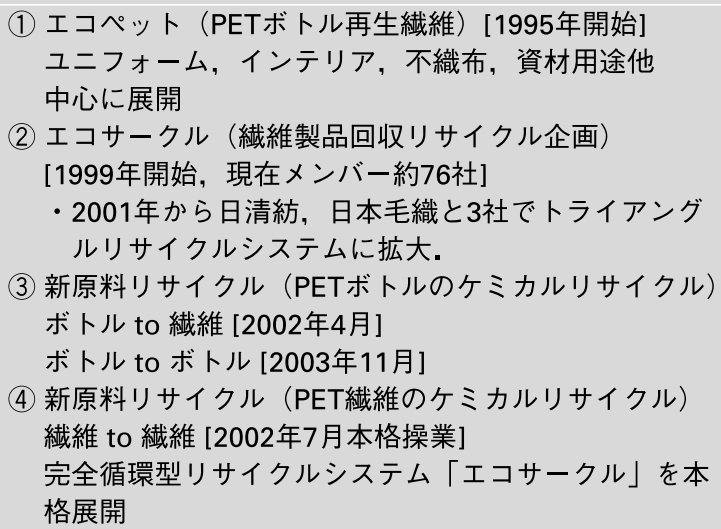 & $\begin{array}{l}\text { リサイクル繊維を用いた手袋，毛布などへの混ぜ物 } \\
\text { [2000年開始] }\end{array}$ \\
\hline 対象素材 & $\begin{array}{l}\text { ・ ポリエステル100\%および80\%以上の複合素材. } \\
\text { ・ 綿100\%, 毛100\%含む綿混・毛混をトライアングルリ } \\
\text { サイクルシステムで対応. (マテリアルリサイクル中心) }\end{array}$ & アクリルのトウ屑 \\
\hline $\begin{array}{c}\text { 展開用途 } \\
\text { 規 模 }\end{array}$ & 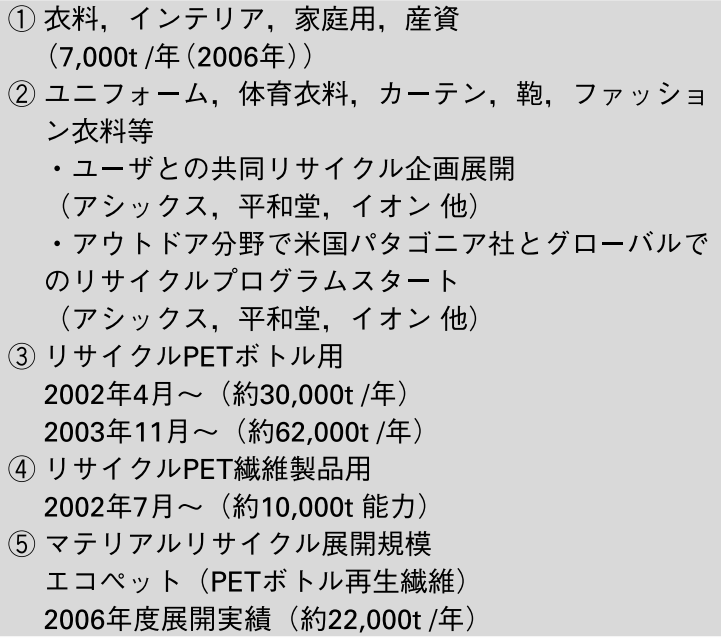 & 上記素材を含むアクリル糸として $30 t$ /月程度を実施. \\
\hline $\begin{array}{c}\text { 易リサイクル } \\
\text { への工夫 }\end{array}$ & $\begin{array}{l}\text { - 副資材を含めたポリエステル化比率の向上推進 } \\
\text { ・帝人ファイバー(株)易リサイクル商品の開発企画推進 } \\
\text { - 帝人ファイバー(株易エコマテリアル基準制定 }\end{array}$ & トウ屑の発生が無くなる為, 在庫綿を効率よく使用できる. \\
\hline $\begin{array}{l}\text { 今後の } \\
\text { 取組み }\end{array}$ & $\begin{array}{l}\text { - リサイクルによって回収制品以上の価値を有する商品 } \\
\text { に再生し, 持続的発展が可能な完全循環型社会形成を } \\
\text { 目指す. } \\
\text { - 感性・機能性の付与によって, 差別化ポリエステル再 } \\
\text { 生絨維 (長織維) の量的拡大を図る. } \\
\text { - 認定商品に識別マークを支給 }\end{array}$ & \\
\hline
\end{tabular}


（2）東レ

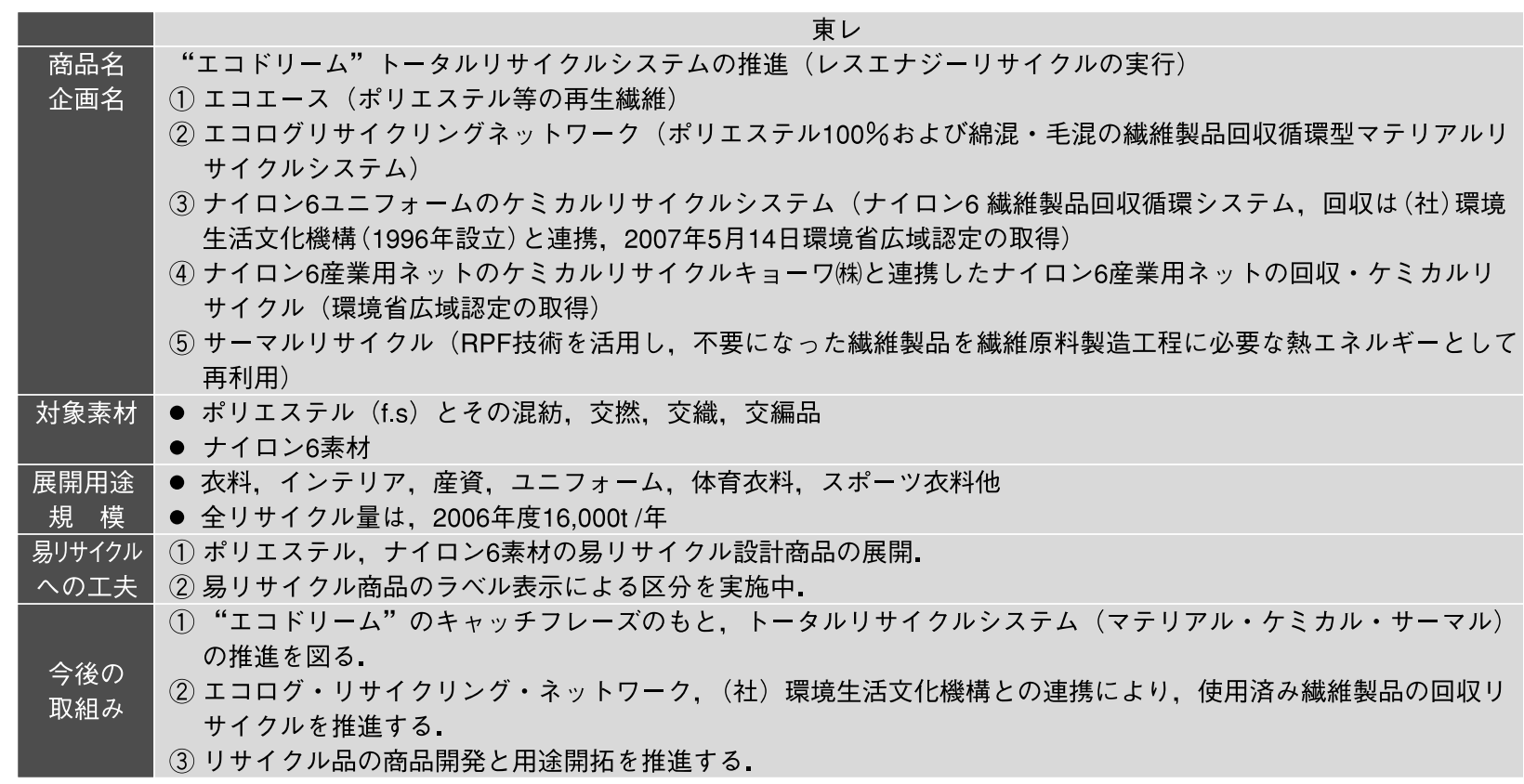

（3）クラレ

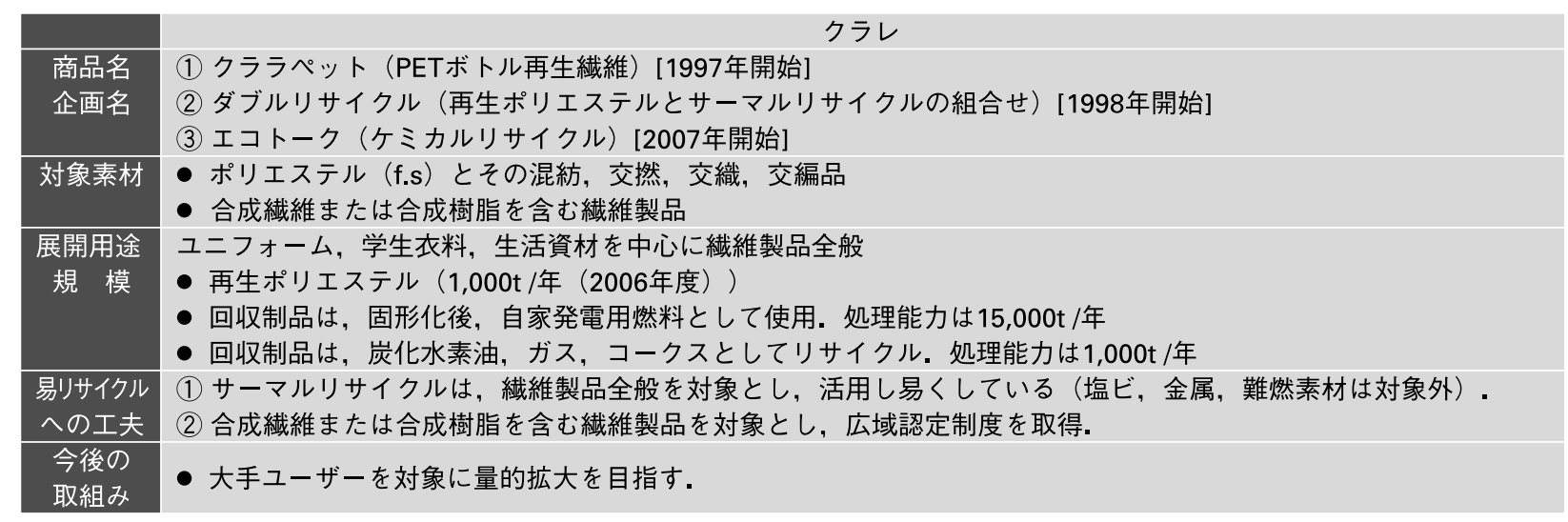

\section{（4）東洋紡}

\begin{tabular}{|c|c|}
\hline & 東洋紡 \\
\hline 商品名 & (1) エコールクラブ（PETボトル再生繊維製品），エコールユミ（同ワタ）[1995年開始] \\
\hline 企画名 & $\begin{array}{l}\text { (2) 製品の回収リサイクルシステム（サーマルリサイクル，マテリアルリサイクル）[1998年開始] } \\
\text { (3) ショッピングサイト「エコールクラブドットコム」[2001年開始] }\end{array}$ \\
\hline 対象素材 & - ポリエステル（f.s）とその混紡, 交撚, 交編品 \\
\hline 展開用途 & (1) ユニフォーム，ワーキングウェア，Tシャツなどの衣料品全般 \\
\hline 規 模 & $\begin{array}{l}\text { (2) 毛布, 布団側地, カーテンなどの寝装, インテリア用品 } \\
\text { (3) 傘, かばん, 買物袋, 風呂敷などの生活雑貨 } \\
\text { (4) ネット, ロープ, スパンボンドなどの一般資材・産業資材 } \\
\text { ・規模は } 2,500 t / \text { 年 }\end{array}$ \\
\hline $\begin{array}{l}\text { 易リサイクル } \\
\text { ヘのエ夫 }\end{array}$ & •サーマルリサイクルのために塩ビ，金属など焼却時に障害となるものを縫製付属品としてできるだけ使用しない. \\
\hline 今後の & (1) エコマークやグリーン購入法をばねにして販売衣料を拡大. \\
\hline 取組み & 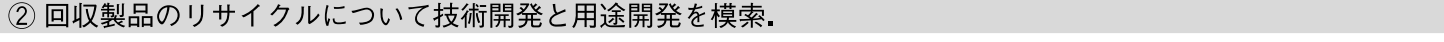 \\
\hline
\end{tabular}


（5）旭化成

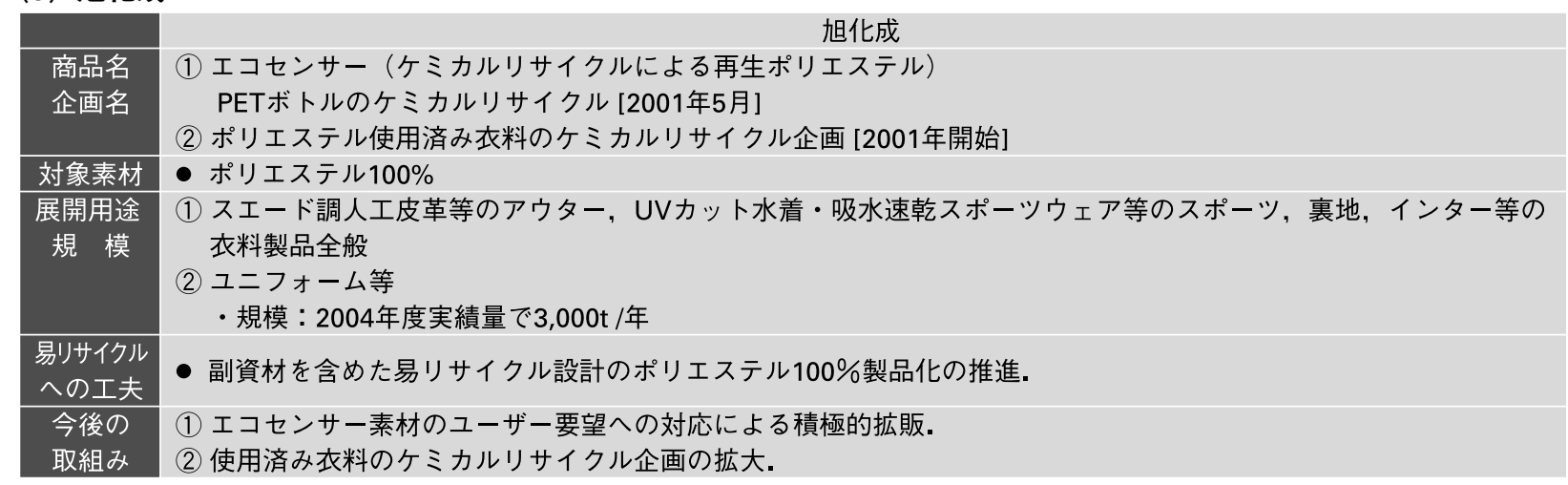

(6) ユニチカ

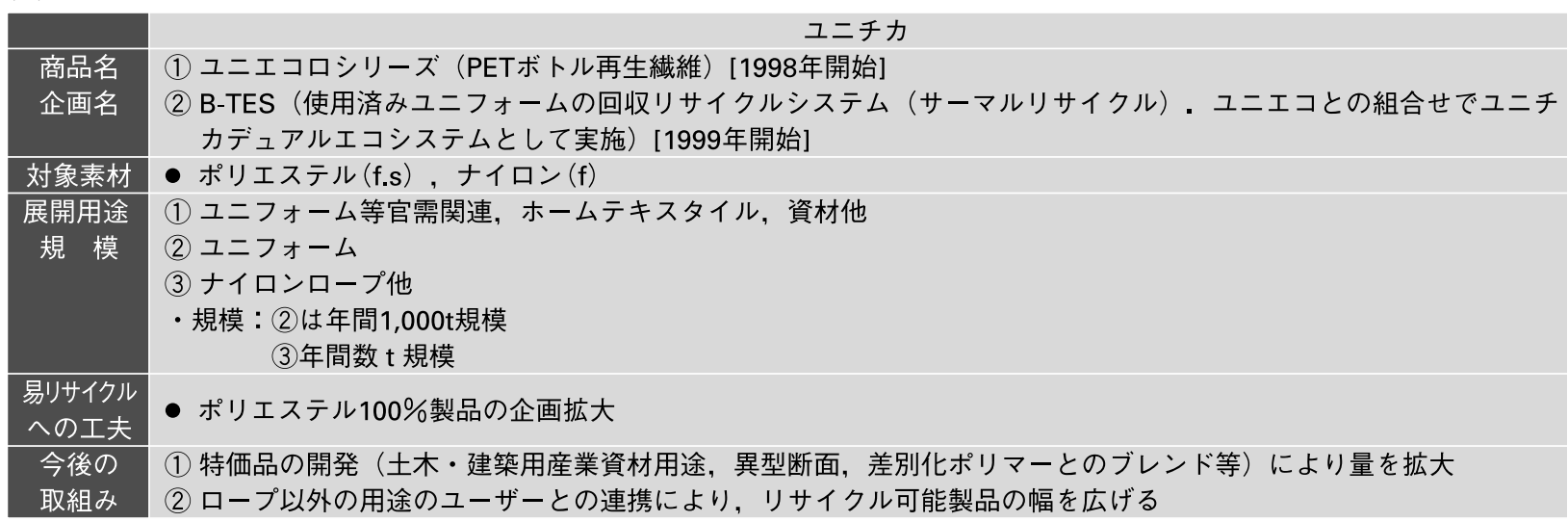

\section{（7）三菱レイヨン}

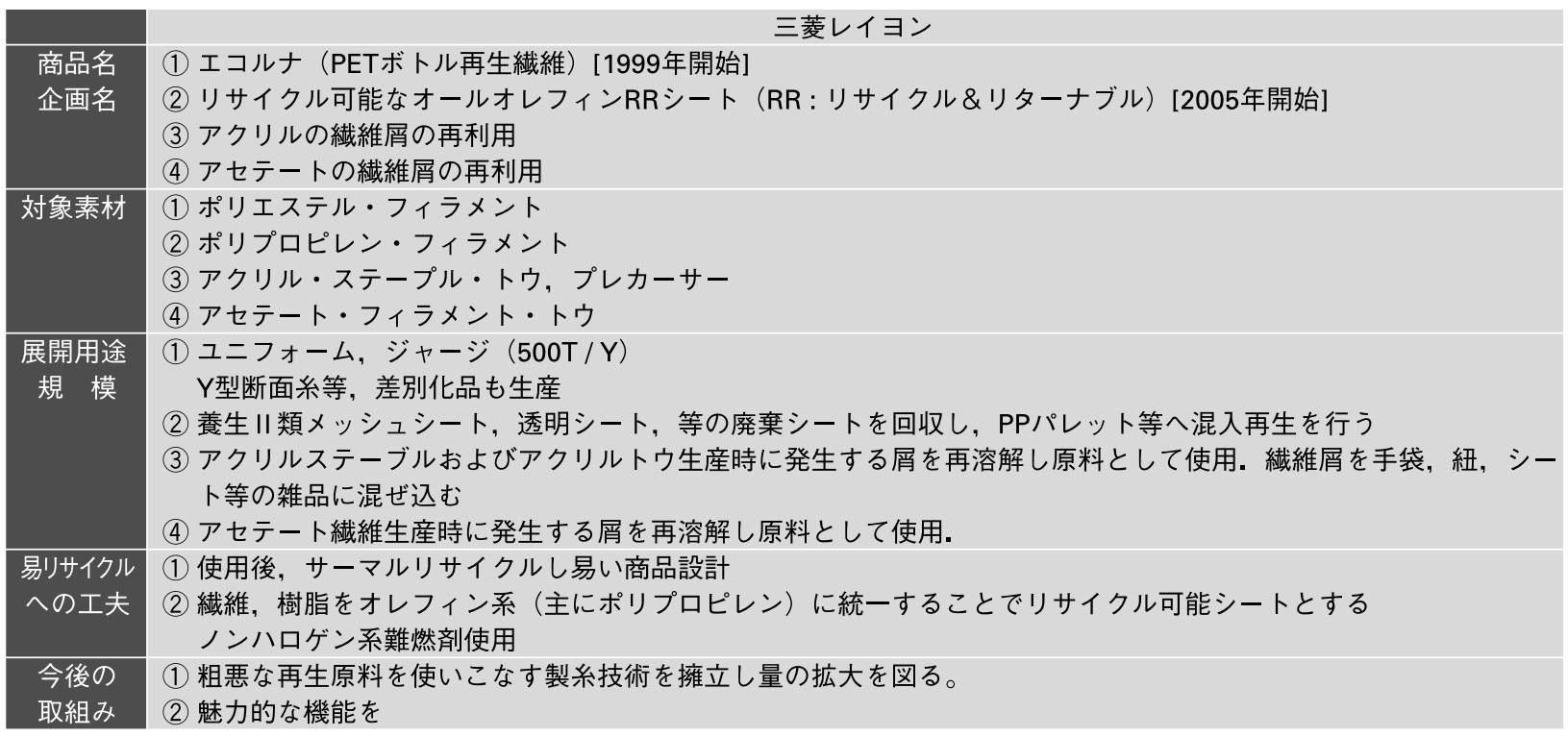

大橋庸二(おおはし ようじ)

昭和 49 年, 東レ(株)入社, 繊維事業本部のテキスタイル営業に従事, 平成 14 年より繊維事 業本部繊維リサイクル室主幹（担当部長）として繊維リサイクル推進業務に従事, 現在に 至る. 平成 17 年より京都工芸繊維大学繊維リサイクル技術研究センター特認教授, 平成 19 年 7 月から同 20 年 6 月まで, 日本化学繊維協会合繊リサイクル専門委員会委員長.

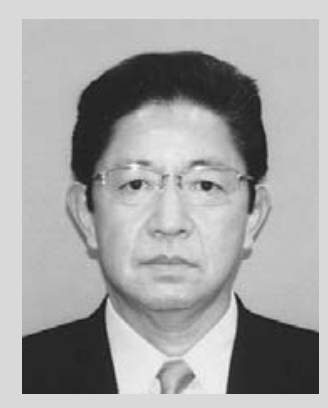

